\title{
A new method for evaluating the effect of antiarrhythmic drugs on atrioventricular nodal conduction
}

\author{
SAMUEL LEVY, JEAN HILAIRE, HENRI ALBIN, JEAN-LOUIS CORBELLI, \\ JEAN-PAUL BURTEY, HENRI BRICAUD, RAYMOND GERARD
}

From the Department of Cardiology, University of Bordeaux, Hôpital Cardiologique, Pessac, France, and the University of Marseille, School of Medicine, Marseille, France

SUMMARY Electrophysiological variables were studied in 19 patients before and after one of three commonly used antiarrhythmic agents. The pacing rate at which alternating Wenckebach periods appeared in eight patients was significantly reduced by intravenous digoxin $(0.01 \mathrm{mg} / \mathrm{kg}$ body weight). The atrioventricular nodal conduction time ( $\mathrm{A}-\mathrm{H}$ interval) and Wenckebach point were not significantly altered by digoxin. Intravenous propranolol $(0.1 \mathrm{mg} / \mathrm{kg}$ body weight) in four patients did not affect the $\mathrm{A}-\mathrm{H}$ interval, but it reduced the pacing rates at which the Wenckebach point and alternating Wenckebach periods occurred. Intravenous disopyramide $(2 \mathrm{mg} / \mathrm{kg}$ body weight) significantly increased the pacing rate required to produce alternating Wenckebach periods but did not significantly alter the other indicators of atrioventricular conduction in seven patients.

It is concluded that the pacing rate required to produce alternating Wenckebach periodicity may be a useful and sensitive variable in the evaluation of the effect of antiarrhythmic agents on atrioventricular nodal conduction.

Intracardiac electrograms and programmed electrical stimulation may be used to study the effect of antiarrhythmic drugs on the electrophysiological properties of the human heart, particularly their effects on the atrioventricular node. These effects may be used to predict the potential success of treatment with various antiarrhythmic agents in patients with supraventricular tachycardias. ${ }^{1}$ Several electrophysiological variables have been used to assess the effect of antiarrhythmic drugs on the atrioventricular node. They include measurement of atrioventricular nodal conduction time (A-H interval) at programmed stimulation, measurement of the lowest atrially paced rate at which a type I second degree atrioventricular block occurs (Wenckebach point), and measurement of refractory periods in the atrioventricular node.

We have measured the effect of digoxin, pro-

Requests for reprints to Dr Samuel Lévy, Centre Cardiovasculaire J Cantini, 8 bis, avenue Védrines, 13009 Marseille, France.

Accepted for publication 3 September 1985 pranolol, and disopyramide on the lowest rate at which alternating Wenckebach periods occur and have assessed whether this variable provides useful information on the effect of these antiarrhythmic agents on the atrioventricular node.

\section{Patients and methods}

Nineteen patients had electrophysiological evaluation after giving informed consent. All drugs were discontinued 48 hours or more before the study. No patient had taken amiodarone in the three months preceding the study. Table 1 gives the clinical and electrocardiographic findings in our patients. Catheters were inserted percutaneously into the femoral vein. One quadripolar catheter was positioned near the sinus node to record and pace the high atrium. A bipolar catheter was positioned across the tricuspid valve to record the His bundle electrogram by standard techniques. ${ }^{2}$ Simultaneous recordings of leads I, II, II, or VI and the intracardiac electrogram were displayed on a multichannel oscilloscope and were 
Table 1 Clinical and electrocardiographic findings in 19 patients

\begin{tabular}{|c|c|c|c|c|c|}
\hline \multirow[t]{2}{*}{ Case } & \multirow{2}{*}{$\begin{array}{l}\text { Age (yr) } \\
\text { and sex }\end{array}$} & \multirow[t]{2}{*}{ Symptoms } & \multirow[t]{2}{*}{ Clinical diagnosis } & \multicolumn{2}{|c|}{ ECG findings } \\
\hline & & & & $P R(s)$ & $Q R S(s)$ \\
\hline \multicolumn{6}{|c|}{ Digoxin } \\
\hline $\begin{array}{l}1 \\
2 \\
3 \\
4 \\
5 \\
6 \\
7 \\
8\end{array}$ & $\begin{array}{l}65 \mathrm{M} \\
80 \mathrm{~F} \\
66 \mathrm{M} \\
60 \mathrm{M} \\
76 \mathrm{~F} \\
74 \mathrm{M} \\
60 \mathrm{M} \\
40 \mathrm{~F}\end{array}$ & $\begin{array}{l}\text { Syncope } \\
\text { Syncope } \\
\text { CHF } \\
\text { CHF } \\
\text { Syncope, CHF } \\
\text { CHF (LV) } \\
\text { CHF } \\
\text { CHF }\end{array}$ & $\begin{array}{l}\text { NHD } \\
\text { NHD } \\
\text { MR } \\
\text { AS } \\
\text { NHD } \\
\text { NHD } \\
\text { AS } \\
\text { CM }\end{array}$ & $\begin{array}{l}0 \cdot 15 \\
0 \cdot 15 \\
0 \cdot 13 \\
0 \cdot 26 \\
0 \cdot 26 \\
0 \cdot 23 \\
0 \cdot 30 \\
0 \cdot 20\end{array}$ & $\begin{array}{l}0 \cdot 11 \mathrm{LAFB} \\
0 \cdot 13 \mathrm{RBBB}+\text { LAFB } \\
0 \cdot 13 \mathrm{RBBB}+\text { LAFB } \\
0 \cdot 15 \mathrm{LBBB} \\
0 \cdot 14 \mathrm{RBBB}+\text { LAFB } \\
0 \cdot 14 \mathrm{LBBB} \\
0 \cdot 18 \mathrm{IVCD} \\
0 \cdot 14 \mathrm{RBBB}+\text { LPFB }\end{array}$ \\
\hline \multicolumn{6}{|c|}{ Propranolol } \\
\hline $\begin{array}{r}9 \\
10\end{array}$ & $\begin{array}{l}56 \mathrm{M} \\
37 \mathrm{~F}\end{array}$ & $\begin{array}{l}\text { Palpitation } \\
\text { Palpitation, } \\
\text { dizzy spells }\end{array}$ & $\begin{array}{l}\text { ASHD, HCVD } \\
\text { NHD }\end{array}$ & $\begin{array}{l}0 \cdot 27 \\
0 \cdot 15\end{array}$ & $\begin{array}{l}0 \cdot 16 \text { RBBB + LAFB } \\
0 \cdot 10\end{array}$ \\
\hline $\begin{array}{l}11 \\
12\end{array}$ & $\begin{array}{l}47 \mathrm{M} \\
38 \mathrm{M}\end{array}$ & $\begin{array}{l}\text { Palpitation, PAF } \\
\text { Palpitation }\end{array}$ & $\begin{array}{l}\text { NHD } \\
\text { NHD }\end{array}$ & $\begin{array}{l}0 \cdot 17 \\
0 \cdot 18\end{array}$ & $\begin{array}{l}0.8 \\
0 \cdot 10 \text { LAFB }\end{array}$ \\
\hline \multicolumn{6}{|c|}{ Disopyramide } \\
\hline $\begin{array}{l}13 \\
14 \\
15 \\
16 \\
17 \\
18 \\
19\end{array}$ & $\begin{array}{l}65 \mathrm{M} \\
41 \mathrm{M} \\
71 \mathrm{M} \\
70 \mathrm{M} \\
57 \mathrm{M} \\
68 \mathrm{M} \\
79 \mathrm{~F}\end{array}$ & $\begin{array}{l}\text { PAF } \\
\text { Dizzy spells } \\
\text { Syncope } \\
\text { Syncope } \\
\text { CVA, PAF } \\
\text { Syncope } \\
\text { Syncope, PAT }\end{array}$ & $\begin{array}{l}\text { ASHD (old MI) } \\
\text { NHD } \\
\text { NHD } \\
\text { NHD } \\
\text { HCVD } \\
\text { NHD } \\
\text { NHD }\end{array}$ & $\begin{array}{l}0.13 \\
0.24 \\
0 \cdot 17 \\
0.20 \\
0.21 \\
0.23 \\
0.16\end{array}$ & $\begin{array}{l}150 \text { IVCD } \\
0.13 \text { RBBB + LAFB } \\
0.10 \\
0.80 \text { LPFB } \\
0.8 \\
0.11 \\
0.9\end{array}$ \\
\hline
\end{tabular}

AS, aortic stenosis; PAF, paroxysmal atrial fibrillation; ASHD, atherosclerotic heart disease; CHF, congestive heart failure; CVA, cerebrovascular accident; CM, cardiomyopathy; HCVD, hypertensive cardiovascular disease; LAFB, left anterior fascicular block; LPFB, left posterior fascicular block; IVCD, intraventricular conduction defect; MI, myocardial infarction; MR, mitral regurgitation; LBBB, left bundle branch block; LV, left ventricular; NHD, no demonstrable heart disease; RBBB, right bundle branch block; PAT, paroxysmal atrial tachycardia.

recorded on a photographic recorder (Electronics for Medicine VR12) at paper speeds of 50 and 100 $\mathrm{mm} / \mathrm{s}$. The high atrium was paced at twice diastolic threshold at rates which increased by 10 beats $/ \mathrm{min}$ for 30 seconds at each pacing rate until a

Wenckebach type I block was achieved; the rate was then increased by 5 beats/min until alternating Wenckebach periodicity appeared. Each pacing rate of our stimulator (Savita, Paris) was checked by a chrono-analyser to allow adjustment to within $1 \mathrm{~ms}$

Table 2 Pharmacological and electrophysiological data

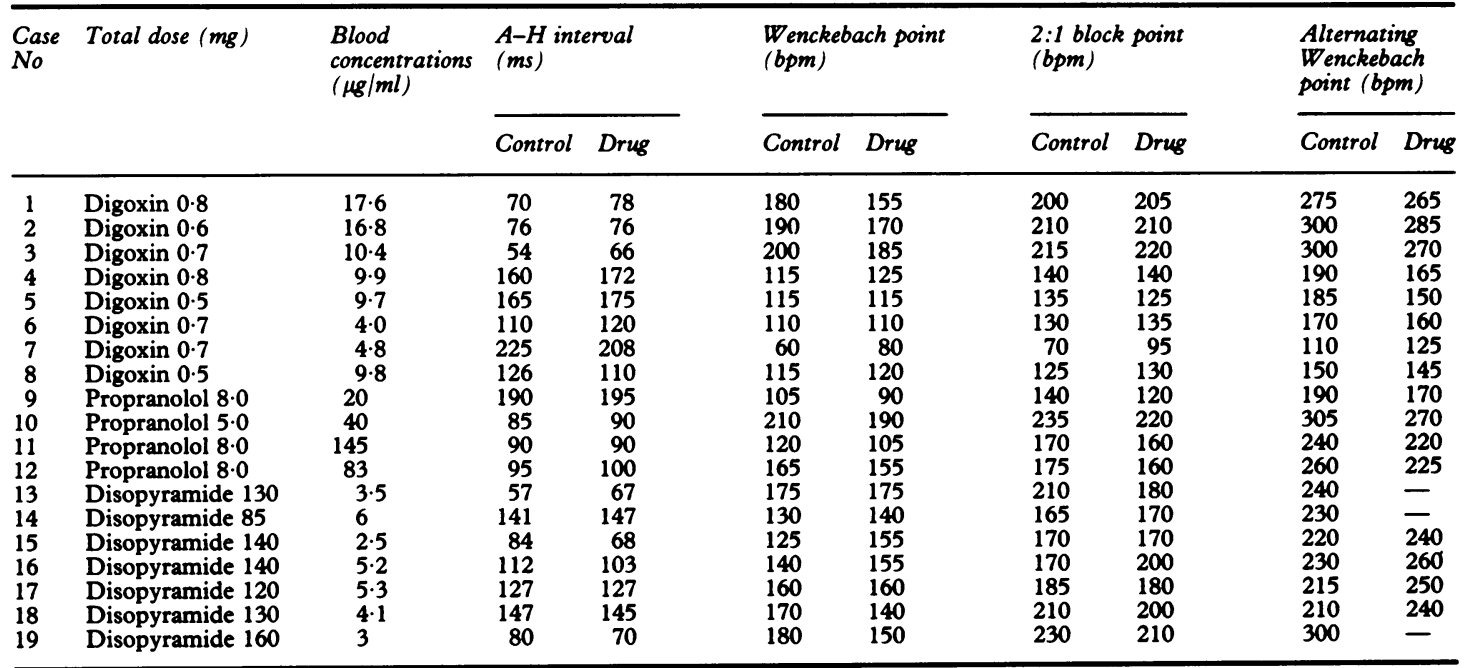

bpm, beats per minute. 


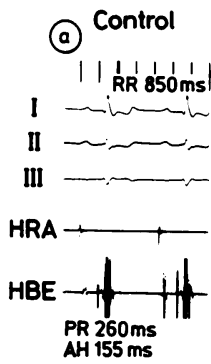

(b)

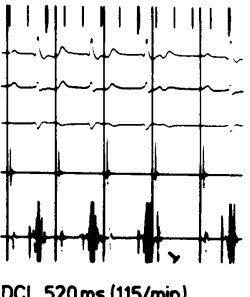

(C)

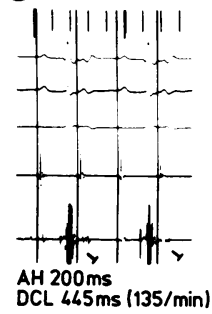

(a) Digoxin

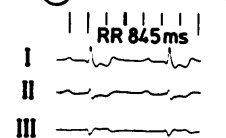

HRA

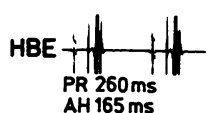

(b)

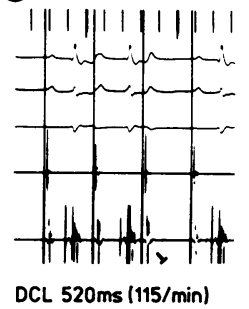

(c)

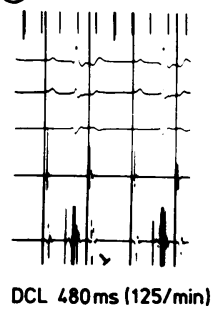

Fig. 1 Effect of intravenous digoxin on $A-H$ interval (a), Wenckebach point (b), and 2:1 block point (c).

Electrocardiographic leads $I, I I, I I I$, high right atrial $(H R A)$, and His bundle electrocardiographic leads (HBE) are shown. Intervals of $200 \mathrm{~ms}$ are shown at the top of the figure. All measurements are in ms. The corresponding rates in beats per min of driven cycle lengths (DCL) are given in parentheses. Blocked atrial beats are indicated.

of the corresponding cycle length. Atrial pacing was started at a cycle length which was $50 \mathrm{~ms}$ shorter than the spontaneous $R R$ interval. We noted the lowest rate at which Wenckebach, 2:1 block, and alternating Wenckebach periodicity appeared. We used extrastimuli to measure the effective and functional refractory periods of the atrioventricular node and atrium. We repeated the study after giving the patient intravenous digoxin $(0.01 \mathrm{mg} / \mathrm{kg}$ body weight over one minute), intravenous propranolol $(0.1 \mathrm{mg} / \mathrm{kg}$ body weight at the injection rate of 1 $\mathrm{mg} / \mathrm{min}$ ), or disopyramide $(2 \mathrm{mg} / \mathrm{kg}$ body weight over five minutes). Blood samples were withdrawn 20,15 , and 10 minutes respectively after the start of injection. Electrophysiological variables were measured 20 minutes after the start of digoxin administration, 15 minutes after the start of propranolol, and 10 minutes after the start of disopyramide-that is immediately after withdrawal of blood samples.

\section{DEFINITIONS}

Alternating Wenckebach periods are episodes of 2:1 atrioventricular block in which conducted $P$ waves show a progressive increase in the interval between the $P$ wave and $R$ wave until two or three successive $P$ waves are blocked. The alternating

Wenckebach point is the lowest pacing rate at which this phenomenon is seen. In our experience alternating Wenckebach periods can be consistently produced in most patients. ${ }^{14}$

Definitions of other electrophysiologic variables are given elsewhere. ${ }^{3}$

We assessed statistical significance by Student's paired $t$ test.

\section{Results}

Table 2 shows the effects of digoxin, propranolol, and disopyramide on $\mathrm{A}-\mathrm{H}$ interval, Wenckebach point, 2:1 block point, and the alternating Wenckebach point. Examples are given in Figs. 1 and 2. The alternating Wenckebach point was reached at a cycle length of $325 \mathrm{~ms}$ ( 185 beats $/ \mathrm{min}$ ). Fig. 2 shows progressive lengthening of stimulus- $\mathrm{V}$ interval due to stimulus- $\mathrm{H}$ interval prolongation until two succeeding paced atrial cycles were blocked. The site of block was established as being in the atrioventricular node by the absence of His bundle deflection after the blocked atrial beats.

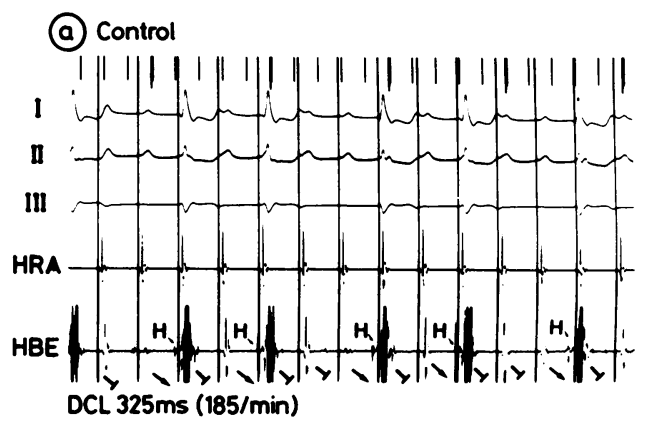

(b) Digoxin

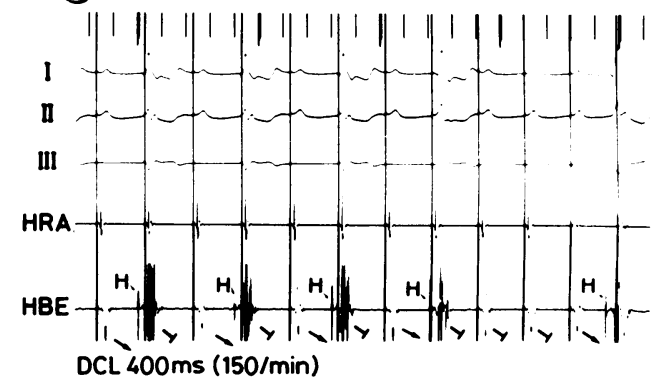

Fig. 2 Effect of digoxin on the alternating Wenckebach periods. The His bundle electrogram shows that the site of the block was the atrioventricular node both during the control test (a) and after intravenous digoxin (b). Digoxin lengthened the shortest cycle length at which alternating Wenckebach periods occurred. Blocked atrial beats and His bundle deflection are indicated. See legend to Fig. 1 for abbreviations. 
Table 3 Effect of digoxin on electrophysiological variables (mean SD))

\begin{tabular}{lllllll}
\hline & $R R(\mathrm{~ms})$ & $P R(\mathrm{~ms})$ & $A-H(\mathrm{~ms})$ & $W(\mathrm{bpm})$ & $2: 1(\mathrm{bpm})$ & $A W P(\mathrm{bpm})$ \\
\hline Control & $910(191)$ & $263(63)$ & $122(57)$ & $135(49)$ & $153(50)$ & $210(72)$ \\
Digoxin & $892(208)$ & $212(60)$ & $124(51)$ & $132(34)$ & $157(47)$ & $195(65)$ \\
Significance & NS & NS & NS & NS & NS & p $<0.025$ \\
\hline
\end{tabular}

W, Wenckebach point; AWP, alternating Wenckebach point.

EFFECT OF DIGOXIN

The effect of digoxin was studied in eight patients. Blood digoxin concentrations were above therapeutic levels in all patients $(10.4(4.9) \mu \mathrm{g} / \mathrm{ml}){ }^{4}$ Digoxin had no significant effect on A-H interval, Wenckebach point, and 2:1 point (Table 3). Alternating Wenckebach periodicity was seen at a significantly lower pacing rate after digoxin, however. Figure 1 shows that digoxin slightly lengthened the A-H interval (panel a) but did not affect the Wenckebach point (panel b). The shortest cycle length at which 2:1 block was observed is longer than the cycle length at which it occurred during the control study (panel c). Figure 2 shows the shortest cycle lengths at which alternating Wenckebach periodicity occurred before and after digoxin. Episodes of alternating Wenckebach periodicity ended with two blocked $P$ waves in the control period and with three blocked $P$ waves after digoxin administration. There was no statistically significant change in the effective refractory period of the atrioventricular node, whereas the functional refractory period increased significantly after digoxin (control 500 (211) ms, digoxin $544(173) \mathrm{ms}$ ).

\section{EFFECT OF PROPRANOLOL}

The effect of propranolol on atrioventricular nodal conduction was evaluated in four patients (Table 4). Blood concentrations ranged from 20 to $145 \mu \mathrm{g} / \mathrm{ml}$. The A-H interval was significantly $(p<0.05)$ prolonged in this small group. Similarly the Wencke- bach point $(p<0.01)$ and 2:1 block point $(p<0.005)$ occurred at significantly lower pacing rates after propranolol. Propranolol also had a statistically significant effect on the pacing rates at which the alternating Wenckebach point was reached (Table 4). The effective refractory period of the atrioventricular node could be measured in only three patients; it was prevented by the atrial refractoriness in one. The number of patients studied after propranolol may not have been sufficient to demonstrate a statistically significant effect. The atrioventricular nodal functional refractory period $(433(35) \mathrm{ms})$ was significantly $(p<0.05)$ increased after propranolol (462 (55) ms).

\section{EFFECT OF DISOPYRAMIDE}

The effect of disopyramide on electrophysiological variables was studied in seven patients. Blood concentrations of disopyramide $(4 \cdot 2(1.3) \mu \mathrm{g} / \mathrm{ml})$ were within the accepted therapeutic range. ${ }^{5}$ The A-H interval did not change significantly after disopyramide, nor did the Wenckebach point or the 2:1 block point (Table 5). The alternating Wenckebach point, however, which was measured before and after disopyramide in four patients, occurred at significantly higher pacing rates after disopyramide. It could not be determined after disopyramide in three patients because 2:1 block occurred at the atrial level at rates which previously captured the atrium. This phenomenon was probably related to the significant $(p<0.05)$ increase of the effective refrac-

Table 4 Effect of propranolol on electrophysiological variables (mean SD))

\begin{tabular}{|c|c|c|c|c|c|c|}
\hline & $R R$ (ms) & $P R$ (ms) & $A-H$ (ms) & $W(b p m)$ & $2: 1(\mathrm{bpm})$ & $A W P(b p m)$ \\
\hline $\begin{array}{l}\text { Control } \\
\text { Propranolol } \\
\text { Significance }\end{array}$ & $\begin{array}{l}957(159) \\
1085(198) \\
p<0.05\end{array}$ & $\begin{array}{l}195(50) \\
201(53) \\
p<0.05\end{array}$ & $\begin{array}{l}115(50) \\
118(51) \\
p<0.05\end{array}$ & $\begin{array}{l}152(48) \\
138(50) \\
p<0.01\end{array}$ & $\begin{array}{l}180(39) \\
165(51) \\
p<0.005\end{array}$ & $\begin{array}{l}248(47) \\
215(41) \\
p<0.005\end{array}$ \\
\hline
\end{tabular}

See footnote to Table 2 for abbreviations.

Table 5 Effect of disopyramide on electrophysiological variables (mean SD))

\begin{tabular}{|c|c|c|c|c|c|c|}
\hline & $R R$ (ms) & $P R$ (ms) & $A-H$ (ms) & $W($ bpm $)$ & $2: 1(\mathrm{bpm})$ & $A W P(b p m)$ \\
\hline $\begin{array}{l}\text { Control } \\
\text { Disopyramide } \\
\text { Significance }\end{array}$ & $\begin{array}{l}835(185) \\
773(135) \\
\text { NS }\end{array}$ & $\begin{array}{l}188(37) \\
192(33) \\
\text { NS }\end{array}$ & $\begin{array}{l}106(34) \\
103(36) \\
\text { NS }\end{array}$ & $\begin{array}{l}154(22) \\
153(12) \\
\text { NS }\end{array}$ & $\begin{array}{l}191(35) \\
187(23) \\
\text { NS }\end{array}$ & $\begin{array}{l}218(8) \\
247(9) \\
p<0.002\end{array}$ \\
\hline
\end{tabular}

See footnote to Table 2 for abbreviations. 
tory period in the right atrium after disopyramide (from 237 (36) to 256 (22) ms). Changes in the effective refractory period $(312(70) \mathrm{ms})$ and the functional refractory period $(422(42) \mathrm{ms})$ of the atrioventricular node after disopyramide (277 (44) and 423 (47) ms respectively) were not statistically significant.

\section{Discussion}

\section{ALTERNATING WENCKEBACH CONDUCTION} Alternating Wenckebach periodicity has been defined as a 2:1 atrioventricular block in which conducted $P$ waves show PR prolongation culminating in two or three consecutive blocked $P$ waves. ${ }^{6-8}$ Langendorf suggested that conduction was blocked in the atrioventricular node and postulated that there were two or more levels at which impulses were blocked in the atrioventricular node. ${ }^{9}$ This concept was extremely useful in the interpretation of complex arrhythmias but the exact level of the block remained hypothetical. Interest in this phenomenon increased with the advent of $\mathrm{His}$ bundle recording which allows more exact localisation of the block. Alternating Wenckebach periods have been reported in the atrium, atrioventricular node, and bundle of His. ${ }^{6-11}$ The most common site was the atrioventricular node. Alternating Wenckebach periodicity may be seen during atrioventricular block, atrial tachycardia, or atrial flutter and it may also be induced by programmed pacing. ${ }^{12-14}$ In a prospective study of 36 patients, we found pacing induced atrioventricular nodal alternating Wenckebach periods in $80.5 \%$. This suggests that this phenomenon is a physiological response of the atrioventricular node to high atrial rates. ${ }^{14}$ The fact that this phenomenon was seen to occur retrogradely (in the ventriculoatrial direction) is further support for this suggestion. $^{15}$

We felt that these results indicated that pacing induced alternating Wenckebach periodicity might provide an interesting and new method of evaluating the effect of antiarrhythmic drugs on the atrioventricular node. The effect of three commonly used antiarrhythmic drugs on usual electrophysiological variables was assessed, with emphasis on those variables known to reflect atrioventricular nodal conduction, as well as the lowest rate at which alternating Wenckebach periodicity was observed.

\section{DIGOXIN}

Digoxin slows atrioventricular nodal conduction both through a direct effect and through vagal stimulation. It also increases the effective and functional refractory periods of the atrioventricular node. ${ }^{1617}$ In our series digoxin did not significantly affect the
A-H interval and Wenckebach point, as it was reported to do in other studies. ${ }^{1617}$ The most likely explanation for these conflicting results is the large proportion of patients with a history of congestive heart failure (six out of eight patients) in our series, since the indirect effect of digitalis through the autonomic nervous system has been shown to be blunted in such patients. ${ }^{18}$ The alternating Wenckebach point was the only variable which changed significantly after digoxin administration.

\section{PROPRANOLOL}

Propranolol had a significant effect on atrioventricular nodal conduction in this series, which was consistent with the findings of others. ${ }^{19}$ Changes in both the alternating Wenckebach periods and the Wenckebach point were statistically significant.

\section{DISOPYRAMIDE}

Data on the effects of intravenous disopyramide on atrioventricular nodal conduction are variable. Our study is consistent with the results of other investigators ${ }^{20-22}$ who found no significant effect of disopyramide on $\mathrm{A}-\mathrm{H}$ interval and Wenckebach point. The prolongation of $\mathrm{A}-\mathrm{H}$ interval found by Birkhead and Vaughan William ${ }^{23}$ may be attributable to the cholinergic blockade performed in patients before disopyramide was administered. The absence of significant change of atrioventricular nodal refractory periods confirms the findings of previous reports. ${ }^{2122}$

The effect of disopyramide on the alternating Wenckebach point could not be determined in three patients because of an atrial block. This is consistent with the effect of the drug on the effective refractory period of the right atrium. ${ }^{2122}$ In the four remaining patients the alternating Wenckebach point occurred at a higher rate after disopyramide, which suggests that disopyramide enhanced atrioventricular nodal conduction, probably because it has an atropine-like effect.

\section{INTERPRETATION OF THE RESULTS}

The alternating Wenckebach point was significantly affected even in patients in whom the Wenckebach point did not significantly change. A possible explanation for this difference is that the fall of blood pressure associated with further shortening of the pacing cycle length during evaluation of the alternating Wenckebach point may facilitate conduction and refractoriness of the atrioventricular node through the reflex increase of sympathetic activity. ${ }^{24}$ But such mechanism would also affect the control variables as well as variables measured after the antiarrhythmic agent had been given. To allow for stabilisation of the haemodynamic effects of pacing, 
incremental pacing was performed at a constant rate for a period of $30 \mathrm{~s}$ for each step. An alternative explanation for the difference is that the short cycle lengths required for measurement of alternating Wenckebach point may further stress the atrioventricular node and thus expose effects of antiarrhythmic drugs on the atrioventricular node too slight to be detected by evaluation of the Wenckebach point.

Our study was performed in patients at rest in the supine position. The results may differ in patients in different posture or during exercise. ${ }^{24}$

Our data suggest that the alternating Wenckebach point may be a useful addition to commonly used electrophysiological variables in the assessment of the effect of antiarrhythmic agents on the atrioventricular node. Studies in a larger group of patients and with other antiarrhythmic agents are needed to confirm these preliminary results.

This work was supported by a grant from the French Society of Cardiology.

\section{References}

1 Lévy S. Effets électrophysiologiques des antiarrhythmiques: leur valeur prédictive des effets thérapeutiques. Arch Mal Coeur 1981; $\mathrm{n}^{\circ}$ spécial, 29-35.

2 Scherlag BJ, Lau SH, Helfant RH, Berkowitz WD, Stein E, Damato AN. Catheter technique for recording His bundle activity in man. Circulation 1969; 39: 13-8.

3 Lévy S. Invasive electrophysiologic studies. Technical aspects and definition of common electrophysiologic variables and their use in the study of antiarrhythmic agents. In: Lévy S, Scheinman M, eds. Cardiac arrhythmias. From diagnosis to therapy. Mount Kisco: Futura Publishing Company, 1984: 57-72.

4 Smith TW. The clinical use of serum cardiac glycoside concentration measurements. Am Heart $\mathcal{f}$ 1971; 82: 833-7.

5 Heel RC, Brogden RN, Speight TM, Avery GS. Disopyramide: a review of its pharmacological properties and therapeutic use in treating cardiac arrhythmias. Drugs 1978; 15: 331-68.

6 Amat-y-Leon F, Chuquimia R, Wu D, et al. Alternating Wenckebach periodicity: a common electrophysiologic response. Am $\mathcal{F}$ Cardiol 1975; 36: 757-64.

7 Halpern MS, Nau GJ, Levi RJ, Elizari MV, Rosenbaum MB. Wenckebach periods of alternate beats. Clinical and experimental observations. Circulation 1973; 48: 41-9.

8 Kosowsky BD, Latif P, Radoff AM. Multilevel atrioventricular block. Circulation 1976; 54: 914-21.

9 Langendorf R. Concealed AV conduction: the effect of blocked impulses on the formation and conduction of subsequent impülses. Am Heart $\mathcal{f}$ 1948; 35: 542-52.

10 Castellanos A, Sung RJ, Aldrich JL, Mendoza IJ, Myerburg RJ. Alternating Wenckebach periods occurring in the atria His-Purkinje system, ventricles and Kent bundle. Am $\mathcal{F}$ Cardiol 1977; 40: 853-9.

11 Slama R, Leclercq JF, Rosengarten M, Coumel P, Bouvrain Y. Multilevel block in the atrioventricular node during atrial tachycardia and flutter alternating with Wenckebach phenomenon. Br Heart $\mathcal{F}$ 1979; 42: 463-70.

12 Schuilenburg RM, Durrer D. Conduction disturbance located within the His bundle. Circulation 1972; 45: 612-28.

13 Guérot $\mathrm{C}$, Valère $\mathrm{PE}$, Castillo-Fenoy $\mathrm{A}$. Le phénomène de Wenckebach du $2^{\circ}$ degré. Etude clinique et électrocardiographique à propos de 10 cas. Arch Mal Coeur 1975; 68: 1185-94.

14 Lévy S, Pouget B, Clementy J, Bemurat M, Bricaud H. Pacing-induced alternate Wenckebach periods: incidence and clinical significance. $P A C E$ 1979; 2: 614-23.

15 Lévy S, Roudaut R, Bouvier E, Obel IWP, Clementy J, Bricaud $\mathrm{H}$. Alternate ventriculoatrial Wenckebach conduction. Circulation 1980; 61: 648-52.

16 Przybyla AC, Paulay KL, Stein E, Damato AN. Effects of digoxin on atrioventricular conduction patterns in man. Am f Cardiol 1974; 33: 344-50.

17 Morena H, Chaltiel MG, Denis B, Gavend M, MartinNoël P. Effets électrophysiologiques chez l'homme de l'association digitalique-bêta-bloquant. Nouv Presse Med 1978; 7: 2703-5.

18 Goodman DJ, Rossen RM, Cannom DS, Rider AK, Harrison DC. Effect of digoxin on atrioventricular conduction. Studies in patients with and without cardiac autonomic innervation. Circulation 1975; 51: 251-6.

19 Seides SF, Josephson ME, Batsford WP, Weisfogel GM, Lau SH, Damato AN. The electrophysiology of propranolol in man. Am Heart $\mathcal{9}$ 1974; 88: 733-41.

20 Josephson ME, Caracta AR, Lau SH, Gallagher JJ, Damato AN. Electrophysiological evaluation of disopyramide in man. Am Heart $\mathcal{f} 1973$; 86: 771-80.

21 Befeler B, Castellanos A Jr, Wells DE, Vagueiro MC, Yeh BK. Electrophysiologic effects of the antiarrhythmic agent disopyramide phosphate. $\mathrm{Am} \mathcal{F} \mathrm{Car}-$ diol 1975; 35: 282-7.

22 Spurrell RAJ, Thorburn CW, Camm J, Sowton E, Deuchar DC. Effects of disopyramide on electrophysiological properties of specialized conduction system in man and on accessory atrioventricular pathway in Wolff-Parkinson-White syndrome. Br Heart $f$ 1975; 37: 861-7.

23 Birkhead JS, Vaughan Williams EM. Dual effect of disopyramide on atrial and atrioventricular conduction and refractory periods. $\mathrm{Br}$ Heart $\mathcal{F}$ 1977; 39: 657-60.

24 Curry PVL, Rowland E, Fox KM, Krikler DM. The relationship between posture, blood pressure and electrophysiological properties in patients with paroxysmal supraventricular tachycardia. Arch Mal Coeur 1978; 71: 293-9. 